\title{
Non-pronominal uses of it: a case study in women's fashion magazines
}

\author{
Isabel Balteiro' \\ Universidad de Alicante
}

\begin{abstract}
The use of English as a global language has largely affected other languages, both in general and specialized areas, particularly at the lexical level due to the massive borrowing of English words. Anglicisms are most visible in the language of fashion, where they are highly appreciated and associated to prestige and "coolness", apart from linguistically representing the rapid advances and modernization of fashion that sometimes make languages unable to cope with the speed with which extralinguistic realities change. The present study, based on a sample of over four million words from leading fashion magazines published in Spanish, focuses on the use of it in its non-pronominal uses, that is, it aims at identifying and describing the adjectival uses of it which may be either directly taken from English in short phrases or compounds like it girl, or adapted to Spanish linguistic contexts as in "calzado it", "más it", "la it prenda". Furthermore, the study also reveals new uses of it, or rather pseudo-English uses that appear in Spanish fashion magazines and which are the result of different linguistic phenomena. In particular, nominal uses like "la "it' del mes", "todas las it" or "nuestras its favoritas" have been detected.
\end{abstract}

Keywords: Anglicisms, pseudo-Anglicisms, non-pronominal it, conversion, fashion language

\section{RESUMEN}

El uso del inglés como lengua global ha afectado en gran medida a otros idiomas, tanto en

1 Corresponding author - Departamento de Filología Inglesa, Universidad de Alicante, Apdo. 99, 03080, Alicante, España

Email: balteiro@ua.es 
general como en campos especializados, sobre todo en el nivel léxico, debido al préstamo masivo de palabras inglesas. Los anglicismos son especialmente visibles en el lenguaje de la moda, campo en el que son muy apreciados al ser considerados como prestigiosos y "cool", aparte de que representan lingüísticamente los rápidos avances y progreso de la moda, que hacen que las lenguas a veces no puedan mantener el ritmo de cambios experimentados por las realidades extralingüísticas. El presente estudio, basado en una muestra de más de cuatro millones de palabras compiladas de revistas de moda destacadas y publicadas en español, se centra en el uso de it en sus usos no pronominales, esto es, pretende identificar y describir los usos adjetivales de it que pueden, bien provenir directamente del inglés en compuestos o sintagmas breves, como "it girl", o bien adaptarse a contextos lingüísticos españoles, como en "calzado it", "más it", "la it prenda". Además, el estudio también revela nuevos usos de "it" como pseudoanglicismos que aparecen en revistas de moda españolas, y que son resultado de fenómenos lingüísticos diferentes. Así, se han detectado, entre otros, usos nominales como "la "it' del mes", "todas las it" o "nuestras its favoritas".

Palabras clave: anglicismos, falsos anglicismos, usos no pronominales de "it", conversión, lenguaje de la moda

\section{Introduction}

The current importance and prestige of the English language, linked to its global dominance and power, have contributed and facilitated the so-called "Anglicization" of European (see Görlach 2001, 2002a, 2002b; Fischer \& Pulaczewska 2008; De Houwer and Wilton, 2011; Furiassi, Pulcini, \& Rodríguez González, 2012, p. 3) and other world languages (Anderman \& Rogers, 2005; Crystal, 2012; Price, 2014; Ai \& You, 2015), as the continuous, increasing and unstoppable incorporation of English borrowings has affected the morphological, lexical, semantic, syntactic and even pragmatic levels of those languages. The lexical component is by far the most commonly affected, probably because vocabulary items are the part of the language that evolves most quickly. More importantly, sometimes languages cannot respond to the changes in extralinguistic realities that have to be named with the required speed, and thus some lexical borrowings are necessarily adopted when a native equivalent (to refer to an extralinguistic reality that the borrowing denotes) is lacking in the recipient language.

Many (European) languages, amongst others, Spanish (in general and in specialised or professional languages) have largely borrowed and been keen to adopt English terms, with or without a real lexical gap. In fact, scholars like Phillipson (2003, p. 72) believe that borrowings are negatively altering the capacity of languages to generate new words or expressions because English elements are displacing and replacing native units and word-formation mechanisms. The impact is so remarkable that it has also facilitated the creation in the recipient languages of autonomous coinages 
which sometimes resemble English words and the appearance of hybrids or even new uses of borrowed elements that do not exist in English, generally known as false Anglicisms (see Furiassi, 2010; Rodríguez González, 2013; Gottlieb \& Furiassi, 2015), which are particularly salient in fashion (see Balteiro \& Campos, 2012; Balteiro, 2014), as will be also seen below.

Our awareness of, and interest in the predominance of Anglicisms and false Anglicisms in fashion in Spanish is one of the main motivations of this paper, together with the scarce number of academic contributions on the language of fashion in general and on the impact of English on other world languages within this LSP. This study explores the borrowing, incorporation and adaptation of the English form it in its non-pronominal uses (e.g. it girl) in Spanish fashion discourse. First, the Spanish linguistic background and its attitudes towards Anglicisms is briefly reviewed (section 2). Then, the language of fashion and also the use of Anglicisms in fashion in Spanish are addressed (section 3). Finally, the empirical study (section 4) focuses on the already mentioned borrowing of non-pronominal uses of it in specialized women fashion magazines: the borrowing of English genuine uses and new non-genuine, apparent or pseudo-English uses of the form it that appear in Spanish are analyzed.

\section{Anglicisms in European Spanish}

Spanish has been, and still is, one of the many European languages to accept English borrowings, despite the resistance exerted by the Real Academia Española (RAE, Spanish Royal Academy), which until very recently tended to favour linguistic purity and the coinage and use of exclusively native elements. However, the globalisation and prestige of English and recent socio-cultural and educational changes, the mass media and the use of the Internet, especially by the youngest generations and specific and/or specialized groups, are the causes of a general feeling of familiarity with and appreciation of English terms, which favour their permeability and integration into present-day Spanish as well as the appearance of analogical creations that imitate English words.

Although the influence of English upon the Spanish language is said to have begun in the Renaissance period, the most frequent, massive and increasing incorporation of Anglicisms actually started in the last decades of the 20th century, which led scholars to discuss whether this phenomenon should be viewed as either enrichment and/or threat or neither of the two. Recent works like Urrutia Cárdenas (2001) and Rodríguez González (2016) follow the traditional approach supported by Pratt (1980) or Lorenzo (1996), which tends to distinguish between "necessary" and 
"luxury" borrowings. A difference is made between, on the one hand, English terms that are adopted in the recipient language, in this case, Spanish, because no equivalent native element exists to refer to a given extralinguistic reality, and hence there is a lexical gap, and, on the other, Anglicisms which do not respond to a lexical need as there is a native term in Spanish to name the extralinguistic reality. The former are usually considered as "natural, neutral and beneficial" Anglicisms (see Pennycook, 1994, p. 9) while the latter are seen as gratuitous and threatening to the essence of the recipient language. Accordingly, Urrutia Cárdenas (2001, p. 13) considers that:

El préstamo extranjero tiene su causa en la ausencia de un significante para designar un nuevo significado. [...] El problema surge cuando por esnobismo o incompetencia en la propia lengua se prefiere el extranjerismo que fácilmente podría ser sustituido por una expresión castellana.

while Rodríguez González (2016, p. 8), quite similarly, argues:

Los anglicismos más admisibles, por inevitables, son los ligados a nuevos referentes; esto es, a nuevas invenciones, nuevas ideas y hasta ahí no hay gran desacuerdo. El problema surge cuando el lenguaje ordinario incorpora voces innecesarias, superfluas, sin que haya intención de elegir la adecuada y precisa en el español, por pereza o esnobismo cultural que nos lleva a utilizar lo que está de moda, como signo de extranjería y de modernidad.

Similar prescriptive approaches are found in earlier classifications like Alfaro's (1970, p. 19), who provides an eleven-category taxonomy where Anglicisms tend to be pejoratively described with terms such as barbarismos crudos, pochismos, etc., but also distinguishes "superfluous anglicisms", from foreign words and neologisms, suggesting the need to avoid unjustified terms, which are used as a sign of snobbery, but highlighting the importance of adopting effective and productive neologisms with no equivalent in Spanish. It is worth noting that this author also considers "pseudoanglicisms", which he defines as Spanish words that may have English paronyms and homonyms, but are used in Spanish in a different way.

Lorenzo (1996) reduces Anglicisms to a five-type classification based on the degree of assimilation of Anglicisms in Spanish: (1) "raw/gross Anglicisms" (anglicismos crudos), that is, those that maintain their English spelling and pronunciation; (2) Anglicisms that are undergoing acclimatisation or adaptation; (3) completely assimilated borrowings; (4) calques or literal translations of English terms; and (5) semantic calques or English meanings that have been allocated to an existing word 
in Spanish. This latter type may in turn be divided into one-word (unimembre) and multiword (plurimembre) calques, depending on whether they consist of one or more constituent words.

Later, Rodríguez González (1999: 132-135) provides a new and even more restricted classification, with only three main types of Anglicisms: (1) borrowings, (2) replacements and (3) pseudo-loans. The category of (1) borrowings comprises (1.1.) completely unadapted Anglicisms, (1.2.) elements with a foreign appearance, and (1.3.) lexical units that are totally assimilated to Spanish. In turn, (2) replacements are divided into (2.1.) translations, which tend to share a similar morphologic structure with the recipient language; (2.2.) renderings, when only a part of the English term is translated into Spanish; (2.3.) creations, when an independent equivalent is influenced by the English form; and (2.4.) semantic loans, when the meaning of an English term is transferred into an already existing word in Spanish. Finally, (3) pseudo-loans or words that look English but that are not recognised as such by English native speakers are classified into lexical, morphological and semantic pseudo-loans.

However, the currently most widely followed classification, as in the present study, is that which distinguishes five categories, namely, adapted, non-adapted/pure Anglicisms, false/pseudo Anglicisms, hybrids and calques, as provided by Furiassi, Rodríguez-González and Pulcini (2012), disregarding the debate on the benefits to the recipient language and the threat to its purity due to the introduction of Anglicisms.

Furthermore, nowadays, probably due to the awareness of actual usage by native speakers, the literature on Anglicisms has taken a turn towards a neutral and purely lexical or pragmatic description of Anglicisms (Andersen, 2014) in the different fields in which Anglicisms are highly attested (see, for example, Gómez Capuz 2004: 23-24). Hence, works like Rodríguez González (1999, 2002, 2013) and Rodríguez Medina (2000), amongst others, account for the presence of English loanwords in general European Spanish, while others concentrate on specialized fields, namely, health science (Alcaraz Ariza, 2000); information technology (Bolaños \& Luján, 2010); economy (López Zurita, 2005); legal system (Sánchez \& Durán, 2002; Campos, 2011); advertising (Luján García, 2010; Rodríguez Medina, 2016; García Morales, González Cruz, Luján García \& Rodríguez Medina, 2016); media (Rodríguez Segura, 1999); film and comedies (García Morales, 2009; Gómez Capuz, 2001); sports (Balteiro, 2011b; Rodríguez González, 2012; Campos-Pardillos, 2015 and Rodríguez Medina 2016); fashion and beauty (Balteiro \& Campos, 2012; Balteiro, 2014; Díez-Arroyo, 2015, 2016a, 2016b), as we shall see below; and even on drugs (Rodríguez González, 
1994); and sex and sexuality (Crespo \& Luján, 2017), amongst many others.

In our opinion, the introduction of borrowings from a "dominant" or more prestigious language is a natural linguistic situation that inevitably occurs when two (or more) languages, in this case, English and Spanish, are in contact (see Balteiro, 2011a) or when one dominant language responds more rapidly to the advances of society, science, business and industrialisation by creating new terms that are subsequently (and necessarily) extended to other languages. However, the adoption and use of true Anglicisms and creation of false ones in Spanish is more complex than it appears at first sight, as it obeys multiple and perhaps sometimes "justified" reasons or causes, as Balteiro and Campos (2012, p. 239-240) explain (see section 3), and is highly dependent on the users' self-projection and their educational, social and even professional backgrounds. In general, Spanish native speakers have not shown extreme reactions against unnecessary Anglicisms nor false Anglicisms. On the contrary, in the Spanish language of fashion, for example, English terms or phrases are never questioned but expected, have positive connotations and are conceived as a sign of "coolness" or prestige, as we shall see below.

\section{Anglicisms in Spanish Fashion Language}

Anglicisms are particularly visible in the language of fashion, where they are highly appreciated and associated to prestige and show the advances, rapid evolution, continuous changes, creativity, trends, innovations and the versatile nature of fashion. Therefore, although in general language and in other specialized languages, Anglicisms have been considered as threats to the purity of the Spanish language, this is not the case in the language of fashion, as we shall explain: English words and English-like words, that is, true and false Anglicisms, provide a feeling of being up-todate and "cool" and also contribute to a perception of in-group belonging.

Within the language of fashion, as in other languages for specific purposes, several subgenres may be distinguished (see Bhatia, 2004, p. 59), from the more technical language of textiles (see Balteiro, 2011a) to the less technical and well-known language of fashion as used in the media. One of the most popular, due to its large number of addressees and its popularized nature, is that used in fashion magazines. Fashion magazine language is "influenced by the highly creative context of the garment industry" and "definitely polysemous, connotative, emotional and persuasive, almost like the language of advertising" (Lopriore \& Furiassi, 2015, p. 199), and as "an integral part of the fashion industry" it is consequently characterized by "the plurilingual and multicultural codes of influential stylists and designers" (Lopriore \& Furiassi, 2015, p. 199). Furthermore, in this subgenre, specialists or 
rather, journalists specializing in fashion, write for informative and persuasive purposes for a non-specialist but highly familiarized, fashion conscious and/or "fashion-addicted" readership. These readers, most often women, unlike other types of audiences, are captivated and encouraged to follow fashion trends through the use of attractive and/or catchy language and images. "Attractive" language in this context means using terms in foreign languages, from the language of prestige par excellence, as these readers tend to have a taste for the different, the snob and the cool. In linguistic terms, this implies the incorporation and acceptance of borrowings from English (see Balteiro \& Campos, 2012). Sometimes Anglicisms replace native lexical elements (e.g. jeans for 'vaqueros', blazers for 'americanas') for the abovementioned reasons (see section 2) but also because of "stylistic choices" as "its nearequivalent native term is too restricted" (Díez-Arroyo, 2016a, p. 38). Sometimes Anglicisms in fashion fill in actual lexical gaps (e.g. 'vestidos cupcake', 'zapatos pinpumps') because, first, the new creation or trend is immediately imported without time for an equivalent in the recipient language,and most probably also because looking for a native equivalent seems unnecessary in this specialized discourse. Furthermore, as Balteiro \& Campos (2012, p. 249) suggest, "the prestige and attraction of English leads speakers to follow what they consider an acceptable trend not only in terms of what they have received from English, but also through parallel coinages" and/or also through pseudo-Anglicisms (e.g. dermolifting), probably due to what these authors describe as "the iconic power of English as a trendsetter".

Phillipson (2003, p. 72) argues that for certain fields like fashion and beauty culture, "the foreign name is simply a must, as it implies a positive connotation for the special trade". In addition, as Balteiro \& Campos (2012, pp. 239-240) mention, there are also other motivations for the adoption of true Anglicisms and creation of false ones in fashion language: (1) Anglicisms may name new notions for which Spanish has no equivalent and, consequently, a lexical need actually exists (e.g. jersey); (2) Anglicisms contribute to lexical convergence and homogenisation among young generations, business people and anyone who may be really keen on fashion (e.g. use of coolhunter instead of "genuinely" Spanish cazatendencias); (3) Anglicisms also achieve greater precision and economy than Spanish terms or expressions, which tend to be longer (e.g. jeans for pantalones vaqueros); (4) the English language itself is a trendsetter; and (5) the use of English "serve[s] to stimulate the reader's feelings and to create a pleasant mood of cosmopolitanism" (Haarmann, 1986, p. 110). Apart from that, we agree with Onysko \& Winter-Froemel (2011, pp. 1551-1553) that "even in cases of incontrovertible duplication, the loanword is seen as introducing meaning nuances that eventually differentiate it from the native word", such as accuracy and specificity of meaning (Cabré, 1999, p. 74), and this is especially true of fashion terms. 
While fashion is a widely explored area of knowledge (see amongst others, Barthes, 1983; Damhorst, Miller-Spillman \& Michelman, 1999; Flügel, 1930; O'Hara, 1986), the language of fashion is still under-researched, despite works like Balteiro (2011a, 2014), Balteiro \& Campos (2012), Díez-Arroyo (2015, 2016a, 2016b), and Lopriore \& Furiassi (2015). The study that follows attempts to contribute to the literature on this field by analyzing the peculiar uses of 'it' in Spanish fashion magazines.

\section{It in Spanish fashion magazines}

\subsection{Objectives and Methodology}

This study intends to analyze and describe the introduction, adaptation and integration of non-pronominal it in Spanish fashion language (e.g. Engl. it boy), by focusing on its uses in specialized fashion magazines. The analysis is based on 333 examples manually extracted from a sample of approximately 4,480,000 words obtained by compiling 140 issues of internationally acknowledged fashion magazines in their Spanish editions (namely, Cosmopolitan, all issues from both 2014 and 2016, and January-September 2017; Elle from February 2016 to August 2017; Glamour only February, April, September, November and December 2016 and January-September 2017; Hola Fashion from June 2016 to September 2017; InStyle from January 2016 to September 2017; Marie Claire from January 2016 to September 2017; Vogue from June 2016 to September 2017). In all cases, the examples were extracted from fragments originally written in Spanish, although those magazines may at times contain some articles or advertisements translated from their English editions.

\subsection{Discussion of Results}

Whenever native or non-native speakers of English who may be familiarized with the grammar of this global language are asked for the category or word-class to which it belongs, the answer is that it is, as dictionaries and grammars attest, a pronoun or, if they are more specific, a neuter pronoun used for the third person singular. Furthermore, if they have some further linguistic knowledge they may even add that it may have subjective and objective pronominal uses. More recently, however, an attributive function, proper of the adjectival category, has been introduced and become so frequent in fashion contexts that this is now found and recorded in dictionaries and is being extended to other fields of knowledge and even to other languages. The Oxford English Dictionary (2017; henceforth, OED), for example, 
includes this use under a new category of it, that of adjective in English:

attrib. [After IT GIRL $n$.; compare also IT BOY n.] Designating a person who or thing which is exceptionally fashionable, successful, or prominent at a particular time, as it bag, it couple, it gadget, etc. Frequently with capital initial.

Although this use or conversion (on this see, for example, Balteiro, 2007) has become common and acknowledged more recently (the OED does not include it before 2008), the first example recorded is from 1997, as the OED also informs us:

1997 Sunday Times 2 Nov. X. 12 Her range of It Bags are attracting a loyal following, especially among supermodels.

As suggested above, the pervasive use of English terms in the field of fashion is more than evident in specialized fashion magazines, probably because they are addressed to a female readership who are ardent fashion and trend followers and for whom Anglicisms exercise attraction and contribute a sense of prestige, modernity and coolness. In our sample, it appears most often in directly borrowed and unadapted complex constructions and/or nouns like it girl or it bag, where it has acquired an attributive or adjectival use, as units of this type have soon and eagerly been incorporated into fashion magazines printed/written in Spanish and in other European languages. Apart from those, it is also used in our sample in adjectival functions modifying Spanish words, probably due to analogy with English constructions like the former. Finally, new uses (mainly, nominal ones) which appear in Spanish and which so far do not exist in English have also been identified and analyzed. In general, it is incorporated into Spanish with different degrees of graphical, morphologic and syntactic adaptation, showing interesting variable forms and contexts. There seems to be a progressive integration from the direct borrowing of English complex it+noun constructions, where it functions as modifier of a noun, to its full incorporation and conversion to a noun as in "Ellas son las grandes its de la ciudad condal". But we believe that before this conversion occurs there is an intermediate stage in which, as our study shows, it is used in constructions with Spanish terms in analogy with the English borrowings, e.g. "it falda" or "accesorio it". 


\begin{tabular}{|c|c|c|c|}
\hline \multirow{3}{*}{ Adjectival use } & $\begin{array}{l}\text { borrowing of complex construction "it } \\
+ \text { English noun" }\end{array}$ & $\begin{array}{c}249 \\
(74.77 \%) \\
\end{array}$ & \multirow{3}{*}{$\begin{array}{c}316 \\
(94.89 \%)\end{array}$} \\
\hline & it + Spanish noun & $\begin{array}{c}4 \\
(1.20 \%) \\
\end{array}$ & \\
\hline & Spanish element/phrase + it & $\begin{array}{c}63 \\
(18.92 \%)\end{array}$ & \\
\hline \multicolumn{2}{|l|}{ Nominal use } & \multicolumn{2}{|c|}{$\begin{array}{c}17 \\
(5.11 \%)\end{array}$} \\
\hline & Total & \multicolumn{2}{|c|}{333} \\
\hline
\end{tabular}

Table 1. "It" distribution according to function

As Table 1 shows $^{2}$, the most frequent use ( $74.77 \%$ of the sample) is that of the direct borrowing of an English phrase or complex construction in which it functions as modifier of a noun (e.g. it shoes, it bag, etc.), followed by similar constructions in which it occupies the prototypical position of adjectives in Spanish, noun+adjective, that is, it postmodifies a fashion-related Spanish noun (e.g. "calzado it", "las chicas it", etc.) in $18.92 \%$ of the cases. Unlike those relatively frequent uses, the use of it as a premodifier of a Spanish noun is, as expected, very rare and, hence, occurs very occasionally in the sample (1.20\% of the cases; e.g. "la it falda", "la it joya", etc.). In line with this, the progressive and full adaptation of it to syntactic contexts in Spanish is evidenced in examples where it has been converted into a noun $(5.11 \%$ of the examples), e.g. "la 'it' del mes" or "una de las its más copiadas".

\subsubsection{Adjectival uses of it}

In 316 examples out of 333 cases (94.89\%) in which it has a non-pronominal use and that have been identified in our sample, it has an adjectival function, that is, it works

2 For a distribution of the adjectival and nominal uses in the different magazines, see Tables 2 and 3 in the Appendix. The frequency of appearances of adjectival and nominal it is also analyzed and reflected in Table 4 in the Appendix. Note that in order to normalize the sample, the total number of it elements or expressions identified in each magazine has been divided by the number of issues per magazine used in the data compilation, as explained in section 4.1 (that is, 33 issues from Cosmopolitan, 19 from Elle, 14 from Glamour, 16 from Hola Fashion, 21 from InStyle, 21 from Marie Claire and 16 from Vogue). Not only in terms of absolute numbers (see Table 2) but also in terms of relative frequency per issue (see Table 4), Hola Fashion and Elle seem to be more receptive to borrowing or rather, to the incorporation of it adjectival and nominal uses, although more data might be necessary to reach more definite conclusions. 
as a premodifier of a head noun. In 249 instances of those (74.77\%), as shown in Table 1, it is part of a longer unit, formed by it + head noun, which has been directly borrowed from English. Therefore, it is certainly modifying the noun that follows it but that modification occurs in English, and the whole unit, be this a noun phrase or a compound noun, is borrowed into Spanish (see 4.2.1.1). There are also other two major types in which it functions as an adjective but the noun modification actually takes place in Spanish. Thus, a noun in Spanish may be pre- or post-modified by it, as explained in sections 4.2.1.2 and 4.2.1.3 below.

In its adjectival uses or in their modifying function in Spanish, it is morphosyntactically invariable and semantically lexicalized, as it is in English. Therefore, it may be argued that its use and features are inherited and determined by those corresponding to the category or word-class in the donor language, in this case, an adjective which has simultaneously undergone both a process of lexicalization and conversion from a closed word-class, a neuter pronoun, to an open word-class, an adjective.

\subsubsection{Direct borrowing of "it + English noun"}

As stated above, in most of the examples identified (249 instances; $74.77 \%$ of the total number of cases in the sample) where it functions as a premodifier of a noun, it belongs to a longer structure with which it is conceived as a whole (e.g. it girl, it colour). Note that the $O E D$, for example, indicates that the attributive uses of it come from "IT GIRL n." (see the introduction to section 4.2). Therefore, though it has an adjectival use in those constructions, that function is created in English, and Spanish simply borrows the whole nominal structure or noun in which it appears as a modifier of the head noun. We may then argue that the Anglicism is "it bag", "it girl", etc. and not only "it", as is certainly the case in those constructions. However, this does not mean that we have to disregard cases like these. On the contrary, they not only are highly and increasingly numerous in Spanish but also "the forerunners" which explain, on the one hand, similar forms in Spanish, created by analogy, and in which the English it is incorporated as an adjective acting as either a pre- or postmodifier of a head noun or even as the head of an adjectival phrase, and, on the other, the appearance of other pseudo-English uses and conversion of the adjective to the noun category, as we shall see below (sections 4.2.1.2, 4.2.1.3, and 4.2.2).

Out of the 249 compound nouns or nominal phrases directly borrowed from English in which it is one of the elements, 200 examples (80.32\%) are different uses of it girl, while in 49 cases (19.67\%) it appears in combination with other nouns, namely, it cat (1 example), it bag/it-bag (32 examples, that is, 18 examples of it bag and 14 of it-bag), 
it places (1 example), it shoes (3 examples), it books (1 example), it-jeans (1 example), it-summer (1 example), it colour (1 example), it factor (1 example), it model (1 example), it boy (4 examples), and it woman (2 examples). These borrowings show high variability as regards spelling: first, only 17 examples (34.69\%) out of the 49 present hyphenation (e.g. it-jeans), while the rest are open forms (e.g. it model) ${ }^{3}$. Some nouns or nominal constructions alternate between non-hyphenated and hyphenated forms, as in:

(1) El último 'it bag' de la 'maison' Longchamp sale al asfalto. [E/le11/2016:27] $]^{4}$

(2) El eterno 'it-bag' rejuvenece con mezclas 'patchwork', pieles exóticas 'prints vintage' y toques étnicos [Elle04/2016:273]

Second, most of the examples (37 cases; $75.51 \%$ of these direct borrowings) are typographically marked, probably to highlight their foreign origin but also to attract the readers' attention. An ample range of possibilities is exhibited through the use of italics (21 cases), inverted commas (10 cases), capitalization (4 cases), inverted commas and bold type ( 1 case) and bold type ( 1 case), as in the following cases $^{5}$ :

(3) Que Lottie (Moss), Lily-Rose (Depp) y Kaia (Gerber) vigilen sus espaldas, hay una nueva it model entre sus filas. [HolaFashion03/2017:42]

(4) De icono musical 'fashion' a gran diseñadora e 'it woman', así es Victoria Beckham. [Elle04/2017:36]

(5) EL NUEVO IT-BAG. [Elle09/2016:103]

(6) Los 'it bags' todavía interesan, pero en el último año el protagonismo es para sus minitallas", dicen desde MýTheresa. [Vogue02/2017:57]

(7) It woman. Misteriosa, minimalista, sofisticada y sobria, así es Vanessa Traina. [Elle07/2016:34]

Even one single noun or expression may display different graphical forms. Good

3 All the magazines analyzed, except for Elle, which presents almost equal numbers of hyphenated and non-hyphenated direct borrowings, follow this tendency.

4 Example sources are indicated with codes, where the name in italics identifies the magazine, the next two numbers indicate the issue's month, the four numbers after the slash indicate the year of publication, and the numbers after the colon identify the page number in which the example was found, e.g [Magazinemonth/year:page].

5 As in the case of hyphenation (see footnote 2), Elle does not follow the general tendency observed in the study and in the other magazines considered in this study. In the former, examples marked by inverted commas prevail, though these are followed by italicized forms. 
evidence of this is it bag, where 10 examples are marked and show certain variability as (1), (2), (5) and (6) above, as well as (8) below demonstrate:

(8) TWINSET LANZA UN NUEVO IT BAG. [G/amour09/2016:268]

Third, these forms are directly borrowed without any apparent formal adaptation in Spanish: gender is simply given by the grammatical context but they inflect for number, following and preserving English rules, as examples (6), (9) and (10) corroborate:

(9) [...] hay una nueva it model entre sus filas. [HolaFashion03/2017:42]

(10) IT-BAGS ETERNOS [Elle11/2016:90]

Fourth, though graphically marked, they are syntactically perfectly integrated into Spanish grammatical structures and contexts. Semantically, they do not exhibit any change of meaning but there seems to be some kind of specialization as regards the potential equivalent terms in Spanish, such as "icono", "del momento" or "de moda", which seem to be vaguer and do not convey all the positive connotations and prestige that it has.

Although the preceding explanation is also valid for the borrowing it girl, we consider that this case deserves some attention due to its relevance as the term that initiates the introduction and subsequent uses of it in Spanish and probably also in English, as the OED seems to indicate. As we shall see below, it girl is more than "la chica icono", "la chica de moda", "la chica del momento" (cf. example (44) below or others like "[...] está haciendo furor entre las it girls más cool del momento" [Cosmopolitan06/2016:34]), "la trendsetter o la que marca tendencias", "la modelo a seguir" and even more than all these together. Thus, Spanish and other European languages have eagerly incorporated this term into their fashion jargon. Despite its popularity and extended use, the term, like similar ones, does not present a unique and/or uniform spelling. Accordingly, its spelling alternates between a hyphenated lexical unit (e.g. it-girl) in 18 cases (9\%) and an open form, that is, without a hyphen linking it and the noun girl in 180 cases (90\%). Apart from those examples, Spanish has also borrowed from English a blend in which it girl has been merged with the clipping Brit, resulting in the form "BR(IT) GIRL" [Elle07/2016:18 \& 124]. This form is obviously marked showing the morphological reanalysis in order to facilitate the readers' (be these native or not) interpretation of the form both in morphological and semantic terms.

In addition, 175 (87.5\%) of the it girl cases are marked (16 hyphenated ones and 159 
open cases) ${ }^{6}$, as above, to indicate the foreign origin of the term and to call the readers' attention. Hyphenated marked examples either appear in italics (as in (11)) or with inverted commas (as in (12)):

(11) No hay it-girl que se precie y no posea un arsenal de camisetas con mensaje en su armario.¿Todavía no tienes la tuya? [Cosmopolitan 04/2014:64]

(12) La firma favorita de las 'it-girls' acaba de aterrizar por todo lo alto en la ciudad condal [Elle 09/2016:103]

Meanwhile, non-hyphenated or open marked cases display more heterogeneity. Thus, they may appear with single or double inverted commas (see examples (13) and (14)):

(13) Más de un millón de personas siguen a esta bloguera que ya es toda una 'it girl' mundial. [Elle02/2016:116]

(14) A la derecha, la "it girl" Bianca Brandolini [Hola Fashion 03/2017:117];

in italics, as in:

(15) De it girl a actriz arropada por Johnny Depp [Cosmopolitan 01/2014:29];

with capitalization of either the whole noun structure or only of the two elements in the noun:

(16) Shop/IT GIRL [Glamour 01/2017:102]

(17) It Girl. \#sistersforlife [Glamour 12/2016:16];

with capitalization and italics as in:

(18) [...] la It Girl next door cuya presencia en fiestas y front rows es imprescindible. [Cosmopolitanm 09/2014:132]

(19) OLIVIA PALERMO (30), IT GIRL NEOYORQUINA [Cosmopolitan 01/2017:35];

6 Note that, unlike Glamour where all examples but for one are unmarked, all the magazines seem to follow the same tendency. Non-hyphenation seems to be "the rule" in all of them, including Glamour. 
in normal type within a grammatical context in italics:

(20) ¿Quién ha dicho que no puede haber dos it girls en una misma familia? [HolaFashion07/2017:42],

and a special case in which only it (and not the whole borrowed element) appears in italics as in:

(21) We love Lupita. Nueva it girl a la vista [Cosmopolitan 05/2014:13]

On the contrary, 25 cases (12.5\%), be these hyphenated or open, are inserted in Spanish sentences, without any graphical marking in relation to the corresponding/given context:

(22) Un palacio de it-girls. [Glamour 06/2017:222]

(23) UN NUEVO ROSTRO QUE SE SUMA YA AL ELENCO DE JÓVENES IT GIRLS QUE MARCAN TENDENCIA. [Hola Fashion 06/2016:13]

(24) Sobre el asfalto, las it girls apuestan por versiones arriesgadas con tonos diferentes por delante y por detrás, superposiciones multicolores y bajos irregulares de varias alturas. [Glamour 02/2017:109]

Apart from the preceding cases, where non-pronominal uses of it in Spanish appear in direct borrowings of English lexical units, it is also an Anglicism and even a pseudo-Anglicism in other Spanish constructions, most often in combination with Spanish nouns, probably by analogy with the aforementioned English borrowed forms.

The word order or position of it with respect to the Spanish noun which it modifies is relatively flexible in these cases, although the most frequent order is determined by that prototypical of the part-of-speech of the recipient language. That is, in Spanish, unlike English, the modifier slot tends to follow the head noun (see section 4.2.1.3). However, few cases break this tendency and follow that of the donor language, where it premodifies the corresponding head noun (see 4.2.1.2).

\subsubsection{2. it + Spanish noun}

In only 4 occurrences out of the 333 in the sample (1.20\%) it appears in a premodifying position in Spanish, apparently imitating or rather following the rule in English by which adjectives precede nouns in noun phrases. This tendency does not seem to be very successful in Spanish as, on the one hand, they actually represent 
$1.26 \%$ of the examples where it has an adjectival function and $5.97 \%$ of the cases in which is used in a construction with a Spanish noun and, on the other, in most of the examples where it is used as modifier of a Spanish noun, it tends to appear in a postposition, that is, after the noun (56 cases, $83.58 \%$ of the instances in which it is used as modifier of a Spanish noun; see below).

We observe that in 3 of those examples, namely,

(25) 'Plisa' con garbo. Te presentamos la it falda [Cosmopolitan 08/2014:5]

(26) La chica de la perla. La it joya [Cosmopolitan 09/2016:4]

(27) Todo sobre tu biker. Así se lleva la it prenda [Cosmopolitan 11/2016:11]

the premodifying function and position of it are justified for its specialized meaning, which is not "ONE OF the it skirts/jewels/clothes" but "THE IT skirt/jewel/cloth" par excellence and which does not need further qualification. Compare these cases with others like (28):

(28) ¿Algún ejemplo? Charlotte Chesnais con su personalísima joyería, J.W. Anderson y sus vanguardistas diseños, o Shrimps, a la que debemos la prenda it de la temporada invernal: los abrigos colorful en piel sintética. [Glamour 04/2016:257]

Unlike the preceding constructions, the fourth example within this type (it + Spanish noun) shows the high degree of integration and assimilation of the form it in its adjectival function in Spanish: it is not only used by itself or within Spanish structures but in combination with Spanish words, replacing general Spanish syntactic structures and word formation mechanisms but also altering internal word structures by replacing morphemes or splinters. Thus, it is merged or blended with the word italiana so that the resulting word constitutes a hybrid blend (on this see Balteiro, forthcoming) which perfectly integrates a foreign element functioning as modifier and a native element acting as head in one single lexical unit. Furthermore, a wordplay is achieved through the complete overlapping, the presence of the two source words and the use of a hyphen which clearly marks the morphological reanalysis (on this see Balteiro, 2016).

(29) It-aliana. Combina como nadie sastres masculinos con 'sneakers' y vestidos bohemios con calzado plano. Bianca Brandolini nos da este mes toda una lección de chic, cómo no, 'made in Italy'. [Elle 08/2017:24]

It is graphically and intentionally marked in order to attract the readers' attention in all these examples either by using italics or by the use of the hyphen and bold type, 
as in the latter case.

\subsubsection{Spanish element/phrase $+i t$}

In 63 cases (94.02\%), out of the 67 where it is used in hybrid combinations, that is, with a Spanish term or construction, which also represent $19.93 \%$ of the occurrences in which it has an adjectival function, it is used after a Spanish term or construction. However, not all these cases are similar, but three different functions of it as adjective must be distinguished: first, as a postmodifier of a head noun, in 55 of those examples (87.30\%); second, as a postmodifier of a pronoun in 1 example (1.58\%); and, finally, the adjective it, used as head of an adjectival phrase, is premodified by "más que" or "más" in only 7 instances $(11.11 \% ; 2.21 \%$ of the uses of it as adjective; $2.10 \%$ of the cases in the sample). As far as we know, this use has not yet been reported in English; hence, it is here considered as a syntactic pseudoAnglicism.

4.2.1.3.1. As a postmodifier of a head noun, it appears in combinations like "accesorio it" (3 cases), "alimento it" (1 case), "aristocracia it" (1 case), "bolsos it" (1 case), "campañas it" (1 case), "calzado it" (1 case), "chica(s) it" (10 cases), "chicos it" (2 cases), "corte it" (2 cases), "destellos it" (1 case), "diseñadora it" (1 case), "diseñadores 'it" (1 case), "fragancia it" (1 case), "generación it" (1 case), "lo it" (1 case), "looks it" (1 case), "melenas it" (1 case), "mirada it" (1 case), "pasión it" (1 case), "peinado(s) it" (2 cases), "piezas it" (1 case), "prenda(s) it" (14 cases), "tendencia it" (1 case), "tono it" (1 case), "trenzas it" (1 case), "universo it" (1 case), "verdura it" (1 case), "zapatillas "it"' (1 case), "zapato it" (1 case).

As expected, for several linguistic and extralinguistic reasons, namely and basically, a foreign term is inserted in a native context and addressing the attention of the addressees, in this postmodifying position and/or function, it is most often used as a marked term (37 cases, 63.63\%), unlike the rest of the construction or context. Thus, in 28 cases it is used in italics, as in (30) and (31); in 6 cases it is used with inverted commas, as in (32), (33) and (34); in 2 cases the context in which it has been inserted is italicized so it appears in normal type (see examples (35) and (36)), while in only 1 example it appears in normal type but with a capitalized ' $I$ ' in an italicized context, as shown in (37) below.

(30) LA ZAPATILLA ES TRENDING TOPIC: Son el calzado it de la temporada.

[Cosmopolitan 01/2016:135]

(31) Cuando se piensa que Alexa Chung ha sido la chica it de la moda duran-

te más de una década [...][Glamour 08/2017:38]

(32) [...] Y EDICIONES DE ESTRELLAS SOLIDARIAS Y DISEÑADORES 'IT' 
[Cosmopolitan 01/2014:53]

(33) Tan poderosa como un par de 'stilettos', Karlie Kloss encarna El ALMA de la fragancia 'it'. [Elle 01/2017:143]

(34) El azul 'dark' tiñe las nuevas zapatillas 'it' de NewBalance [Elle 04/2016:88]

(35) RESCATA TU SELLO. De los joyeros de la nobleza a los tocadores de las chicas it. [Hola Fashion 03/2017:60]

(36) Es, sin duda, el corte it del verano: el nuevo wavy bob se caracteriza por un aire desenfadado, casi travieso. El equipo de Cheska nos da las claves del look de moda. [Hola Fashion 06/2016:50]

(37) Ondas sexys, coletas con volumen, trenzas laterales... Los peinados It no son exclusivos de jovencitas egobloggers de Instagram. [Cosmopolitan 02/2014:153]

Nineteen non-marked uses (33.92\%), however, have also been reported, most (13 cases) were found in the same magazine, namely Glamour, which makes us think of an in-house stylistic feature (see also footnote 5), though there is a relatively great variety of contexts as regards graphical forms and spelling. Thus, it is simply inserted without any typographical mark in a normal-type sentence in 10 cases (as in example (38)), in a capitalized normal-type context in 9 cases (as in (39) below), and in an italicized context in only 1 example (as in (40)).

(38) Inspírate en nuestras propuestas y da la bienvenida al nuevo it bag. [Glamour02/2016:22]

(39) GROUPIE. LA MÚSICA Y SUS REFERENCIAS INSPIRAN LOS LOOKS IT DEL OTOÑO. [Glamour 09/2016:348]

(40) Se configuran como los nuevos chicos it a los que seguir en redes sociales [Cosmopolitan 04/2016:24]

Marked and unmarked choices do not depend on the accompanying word or phrase but, as mentioned, on other linguistic or extralinguistic causes. Accordingly, variability is found with the same head element, as in:

(41) ACCESORIO 'IT' “Un buen bolso es imprescindible. [...]" [InStyle 03/2016:142]

(42) $[\ldots]$ los Dioressence son un accesorio it y ultrafemenino, [...][Elle 03/2016:93]

In addition, it is to be noted that the use of it as an adjective in postposition to the modified noun does not mean that it acquires the inflectional plural marks prototypical of adjectives in Spanish, although it is almost perfectly inserted in the 
Spanish grammatical structure. The tendency in these cases is a deviation from the Spanish norm, the adjective not being altered for plural inflection (see, amongst others, examples (43) to (45)), probably as a residual inheritance of the Anglicism or use of it in English which is here copied or imitated, though it may also be due to the intrinsic nature of the word it.
(43) Los prescriptores del futuro son los nuevos chicos it [Cosmopolitan 04/2016:9]
(44) Así son las chicas it del momento. [MarieClaire 07/2016:70]
(45) LAS TRENZAS IT [Hola Fashion 08/2016:57]

4.2.1.3.2. Spanish, unlike English, allows the postmodification of a neuter pronoun by means of an adjective, e.g. "lo bueno", "lo maravilloso", "lo genial", "lo interesante", etc. The example below, the only one found in the sample, seems quite exceptional or rare, considering the large number of examples compiled for this study. However, example (46) also demonstrates the high degree of integration of it in the grammatical structure of Spanish, though it is a pseudo-English use:

(46) Dónde encontrarla: en el epicentro de lo it. Desde el último desfile de Chanel hasta la fiesta posdesfile de Victoria's Secret, pasando por la alfombra roja de Cannes. [Hola Fashion 02/2017:46]

4.2.1.3.3. Similarly to the preceding example, the non-marked use of it in the structure "más que it" (1 case; see example (47)) or in the graphically marked "más it" (6 cases; examples (48) to (51)) are actually pseudo-English uses, as no similar cases have yet been reported or identified in English. In (47) the adjective it is premodified by the intensifying structure "más que" while in examples (48) to (51), it is premodified by "más" and this, "más it", and simultaneously modifies a previous nominal (e.g. (48), (50) and (51)) or a pronominal form (as in (49)).

(47) MÁS QUE IT, EL NUEVO CLÁSICO [Glamour 02/2016:44]

(48) EN TALLA BRILLANTE CON 'A' DE AMY ADAMS Símbolo de identidad y rebeldía en los años 80 , los pendientes más it de la temporada, los ear-lobes (que recorren el lóbulo sin necesidad de perforar la oreja), se convierten en una joya de lujo, insignia de la elegancia, gracias al brillo atemporal de los emblemáticos cristales de Swarovski. [InStyle 06/2016:23]

(49) Quería ser abogada para ayudar a la gente; huele a Santal33; quiere tener siempre cerca a su familia y amigos - los más it de Milán - y ha pasado de musa de street style - así se dio a conocer - a cantante. [Vogue 11/2016:104]

(50) LOS METÁLICOS DE LA TEMPORADA Samsung Galaxy 87 edge viene 
ahora en los nuevos colores más it que han triunfado entre las celebrities, Silver y Pink Gold. Además de su espectacular diseño en colores y acabados metálicos, combina la tecnología más innovadora para convertirlo en el it bag de la temporada, donde podrás guardar todas tus fotos y vídeos, en su memoria ampliable de hasta 200 GB con una tarjeta micro SD, e incluso pagar gracias al nuevo servicio Samsung Pay. [Vogue 06/2016:72]

(51) VIVE LAS ÚLTIMAS TENDENCIAS JUNTO A MARTA ORTIZ, EL ROSTRO MÁS 'IT' DE LA MODA. [Hola Fashion 04/2017:23]

As in the examples in the preceding subsection, it shows a remarkable level of integration in Spanish grammar due to its use with the most prototypical and idiosyncratic Spanish structures; however, it noticeably remains invariable for number. These may be due to purely linguistic causes, amongst others, the English inheritance, recognizability factors, the cacophony that its pluralization may produce in certain phonological contexts as well as the potential difficulty of Spanish speakers to produce the consonant cluster /ts/.

\subsubsection{Nominal uses of it}

While in English a conversion has taken place from a pronoun it (a closed-class category) to adjective (an open-class category), later transferred or borrowed into Spanish, in Spanish a new conversion seems to have taken place from adjective to noun. This nominal use of it, as just explained, does not occur in English. Curiously enough, while English seems to be the language of conversion par excellence, the use of it or its (plural form) has not been found in English7.

In Spanish, however, there seems to be a total conversion from the adjective wordclass to the noun category. Accordingly, it (n) occupies the syntactic slot and position prototypically and functionally defined for (head) nouns in nominal phrases in Spanish, e.g. "ASÍ SON LAS NUEVAS IT, Y LLEGAN PISANDO FUERTE." [HolaFashion02/2017:45]. Semantically, it as a converted noun does not denote a new concept but it refers to the entity whose name occupied the noun position in the deep structure of the phrase in which it is inserted. That is, we argue that in examples like the former, "LAS NUEVAS IT", it is used in the noun position and, hence,

7 In a Google Search its appears only in a music group name (https://myspace.com/theits) and in examples of initials like "The ITS 2016 Winners", where ITS stands for "International Talent Support" (http://www.itsweb.org/jsp/en/newsdetails/id news-2016-07-17-ITS2016winners.jsp), which obviously have no relation to the case in point. 
converted from the adjective word-class, due to the ellipsis of the noun "girls" which is, in Chomskyan terms, present in the deep structure. Therefore, it may also be said to occupy the "semantic gap" left by the omission of a head noun whose referent is so obvious that it has become unnecessary. Interestingly enough, it noun only refers to "it girl(s)", a use that may be justified not only by being the precursor of this type of constructions, to the extent that the OED considers it as a compound noun, but also by its lexicalization and the comparatively high frequency of occurrence of this combination in relation to similar expressions, as above. In spite of this, we cannot disregard the fact that these uses may later be extended to denote other referents (though not yet attested) but these will have to be contextually unambiguous. Morphologically, though conversion does not imply any formal change per se, the converted elements tend to acquire the inflectional features proper to the new word-class. Thus, in "Es una de las its más copiadas" [Hola Fashion 11/2016:38], it is inflected for plural as nouns are. Note that, as seen above, its adjectival use is invariable and as such it does not show plural inflection even when used in grammatical contexts or nominal phrases which require a plural form.

Nevertheless, in the sample there are only 9 cases (52.94\%) out of the 17 in which it has been fully converted to or rather, is a noun (a relatively low number of examples, 5.10\%, if compared to its adjectival uses), a pseudo-English noun ${ }^{8}$. It perfectly fits the grammatical structure of the Spanish sentence in which it is inserted and may be said to be totally converted into a noun and used either in the singular (4 cases, as exemplified in (52) or (53)) or in the plural (5 examples, as in (54) to (58) below), depending on the grammatical features of the surrounding elements, be these determiners, modifiers, etc. As shown, it (noun) is always marked with italics (or even with normal font type because it is inserted in an italicized context), except for two cases (see (52) and (61)), where single inverted commas also serve to highlight this lexical unit in the given contexts:

(52) Inspírate en el look de la 'it' del mes y ficha sus prendas favoritas de la firma española [Cosmopolitan 01/2014:103]

(53) Bianca Brandolini (París. 1987) y Eugenie Niarchos (Nueva York, 1986) forman parte de esa aristocracia de la moda que, mucho antes del uso y abuso de las categorías de it e influencer, disfrutaba de privilegios. [Vogue 03/2017:122]

(54) Casada con Carlo Borromeo, es la diseñadora it de las its italianas. [Vogue 12/2016:241]

Note that Hola Fashion seems to show some preference for these pseudo-English converted nominal uses, which appear as marked cases in italics. Accordingly, 13 examples (out of the 17 in the sample) were identified in this magazine. 
(55) Visto el poder mediático que tienen estas its, no nos extraña que, dentro de muy poco, este peinado se ponga de moda entre las más jóvenes. [Hola Fashion 09/2016:125]

(56) A veces las redes sociales son la ventanita gracias a la que nos acercamos a la vida de nuestras its favoritas. [Hol aFashion 10/2016:196]

(57) OLIVIA PALERMO Es una de las its más copiadas y, por mucho que pase el tiempo, su estilo evoluciona y nos gusta cada vez más. [Hola Fashion 11/2016:38]

(58) ELLAS SON LAS GRANDES ITS DE LA CIUDAD CONDAL. [Hola Fashion 04/2017:117]

Examples ((54) to (58)) show the total integration and conversion of it as a noun in the corresponding grammatical structures, as it functions as head of noun or nominal phrases and it may and can be either pre- or post-modified, or both types of modification may simultaneously affect this converted noun (see (58)), behaving as any other noun in Spanish. Even more important seems the fact that it is also coordinated with other nouns as in (53), as no coordination of two lexical items is theoretically possible in Spanish, unlike in English, unless they belong to the same category or word-class.

Contrary to those, in 8 cases (47.05\%) it may be said to be only partially converted to noun as it is used in singular though inserted in a plural grammatical context, probably due to the weight that the English inheritance and its adjectival use still have. Quite noticeable is also the fact that 7 of those examples appear in the same magazine, which may serve as an indication of its particular linguistic or stylistic preferences. As in previous examples, all these cases are graphically marked, either by using italics ( 5 cases, as in (59)), by using normal type if the grammatical context is in italics (1 case, as in (60)) or by inserting inverted commas (1 case, as in (61)).

(59) Se lo llevas viendo hace tiempo a todas las it, te encanta, pero... ¿cómo me lo pongo?, ¿pareceré una abuela?, ¿me sentará bien? Te damos todas las claves para que apuestes por ellos. [Cosmopolitan 01/2017:42]

(60) Cómo restar elegancia al negro sin perder un ápice de estilo: decorándolo con tachuelas, botones, argollas... Así lo llevan las it. [Hola Fashion 02/2017:34]

(61) Casi cualquier cosa que las 'it' de hoy, siguiendo los tendencias, lleven a la calle, ella ya lo llevó y lo convirtió mucho antes en hits de estilo. [Hola Fashion 07/2017:146]

A great variability is, hence, attested in the sample. On the one hand, examples like "ASÍ SON LAS NUEVAS IT, Y LLEGAN PISANDO FUERTE" [Hola Fashion 02/2017:45] appear in the same magazine next to others like "ELLAS SON LAS GRANDES ITS DE LA 
CIUDAD CONDAL" [Hola Fashion 04/2017:117]. Some would probably argue that a progressive change and adaptation is taking place. However, we are not in the position to prove this statement as, first, not only more data are required but, most importantly, diachronic data including a longer period (ours are mostly from 2016 and 2017); secondly, these two examples belong to two consecutive years and to the same magazine (Hola Fashion 2016 and Hola Fashion 2017, respectively). On the other hand, the selection or use of it or its as noun in plural grammatical contexts seems to depend on the postmodification of the term. Accordingly, unless for example (61), in the remaining 7 examples in which the noun it does not inflect for plural as required by the grammatical context, there is no post-modification of the form but rather, a pause or a predicate follow, as in (59), (60) or in:

(63) LAS IT PONEN DE MODA LOS RELOJES DIGITALES DE LOS 80. [Hola Fashion 07/2016:81]

Note, however, that when it appears in its plural form there is both predetermination and post-modification, but for the case of "estas its" (see example (55)), where the pluralization seems to be almost compulsory probably due to the deictic function of "estas" (in English "these").

These pseudo-English uses of it as noun in Spanish show interesting morphological vacillations which may require further study based on diachronic data in the future.

\section{Conclusions}

As seen in the preceding sections, English terms in general and particularly in fashion language, change quickly, are precise, prestigious and trendy so that fashion followers are usually eager to accept these terms and even imitate such usage as they wish to sound "specialized" and "cool". Thus, unlike in other language fields, Anglicisms and pseudo-Anglicisms are not considered as threats to the purity of the language in fashion. In addition, as in the case of adjectival and nominal uses of it in Spanish, even if similar but not pure or accurate equivalent terms exist in the recipient language, the English form is considered specialized and more precise, conveying some nuances that Spanish partial equivalents cannot provide. Therefore, it may be argued that lexical units like it, given its adjectival and nominal uses or functions, serve to increase the lexical resources of the Spanish language.

Although the main tendency seems to be to borrow pure and unadapted English terms (e.g. it girl), the Spanish fashion language displays a wide range of possibilities as regards different degrees of morphological and syntactic adaptation, font types 
and spelling of the borrowed items, analogical forms and even pseudo-English uses, functions and forms "imitating" actual English models, as shown in the preceding sections. Interestingly enough, and probably due to reasons of recognizability and to call readers' attention, despite the general high degree of integration of the form it in both its adjectival and nominal uses, evidenced in its syntactic functions and in its merging with native forms creating hybrid blends, it most often appears as a graphically marked term. Markedness is intrinsic to any borrowed item due to its foreign nature but this is also increased in written texts by the use of italics, bold type, inverted commas, capitalization, etc., as shown in the analysis above.

This study, however, does not exhaust the analysis of it and its occurrences in fashion discourse and other specialized languages. As mentioned above, a larger amount of diachronic data should be used in future studies in order to prove whether there is a continuum from pure borrowings or "quotation words" (Görlach, 2003) to the creation of analogical forms and pseudo-Anglicisms and later to even conversion or functional shifts of borrowed elements, which may progressively acquire grammatical markers proper of the new word-class.

\section{Article history}

Paper received: 24 October 2017

Paper received in revised form and accepted for publication: 08 November 2017

\section{About the Author}

Dr. Isabel Balteiro is a Senior Lecturer in the Department of English at the University of Alicante (Spain), the leader of the LEXESP research group and the editor-in-chief of "Revista Alicantina de Estudios Ingleses" (RAEI). Her teaching and research focus on English Lexicology and English for Specific Purposes, with special emphasis on word-formation mechanisms, which made her obtain two national awards in 2007 and 2008 for two monographs on conversion and its directionality. Furthermore, Dr. Balteiro specializes on lexical influences in weak or casual language contact situations between English and Spanish. She has published quite extensively on the presence of Anglicisms and false Anglicisms in general Spanish and in specialized or professional languages. Amongst others, special mention may be made of her works on the influence of English in the 
language of real estate, sports, and mainly fashion. Dr. Balteiro is also a member of the Global Anglicisms Database network.

\section{References}

Ai, H. \& You, X. (2015). The grammatical features of English in an Internet discussion forum. World Englishes, 34(2), 211-230.

Alcaraz Ariza, M.A. (2000). Anglicismos en el lenguaje de las ciencias de la salud. Alicante: Universidad de Alicante.

Alfaro, R. (1970). Diccionario de anglicismos. Madrid: Gredos.

Anderman, G. \& Rogers, M. (Eds.) (2005). In and Out of English: For Better, For Worse? Clevedon: Multilingual Matters.

Andersen, G. (2014). Pragmatic borrowing. Journal of Pragmatics, 67(1), 17-33.

Balteiro, I. (2007). A Contribution to the Study of Conversion in English. Münster/New York/München/Berlin: Waxmann Verlag.

Balteiro, I. (2011a). A few notes in the vocabulary of textiles and fashion. In I. Balteiro (Ed.), New Approaches to Specialized English Lexicology and Lexicography (pp. 83-96). Newcastle: CSP.

Balteiro, I. (2011b). A reassessment of traditional lexicographical tools in the light of new corpora: Sports Anglicisms in Spanish. International Journal of English Studies, 11(2), 23-52.

Balteiro, I. (2014). The influence of English on Spanish fashion terminology: -ing forms. ESP Today, 2(2), 156-173.

Balteiro, I. 2016. A look at metalinguistic jokes based on intentional morphological reanalysis. In L. Ruiz-Gurillo (Ed.), Metapragmatics of humor: Current Research Trends (pp. 127-143). Amsterdam: John Benjamins.

Balteiro, I. (forthcoming). Emerging hybrid Spanish-English blend structures in Spanish: 'Summergete con socketines'. Lingua.

Balteiro, I. \& Campos, M.A. (2012). False Anglicisms in the Spanish language of fashion and beauty. Ibérica, 24, 233-260.

Barthes, R. (1983). The Fashion System. New York: Hill \& Wang.

Bhatia, V.K. (2004). Words of written discourse: A genre-based view. London: Continuum.

Bolaños Medina, A. \& Luján García, C. (2010). Análisis de los anglicismos informáticos crudos del léxico disponible de los estudiantes universitarios de traducción. Lexis, 34(2), 241-274. 
Cabré, M.T. (1999). Terminology. Theory, Methods and Applications. Amsterdam: John Benjamins.

Campos, M.A. (2011). False Anglicisms in Legal and Business English as a Lingua Franca (ELF): A Process of Back-Borrowing. In I. Balteiro (Ed.), New Approaches to Specialized English Lexicology and Lexicography (pp. 83-96). Newcastle: CSP.

Campos-Pardillos, M.A. (2015). All is not English that Glitters: False Anglicisms in the Spanish Language of Sports. Atlantis, 37(2), 155-174.

Crespo Fernández, E. \& Luján García, C. (2017). Anglicisms and Word Axiology in Homosexual Language. Revista Española de Lingüística Aplicada RESLA, 30(1), 74-102.

Crystal, D. (2012). English as a global language. Cambridge: Cambridge University Press.

Damhorst, M.L., Miller-Spillman, K.A. \& Michelman, S.O. (1999). The Meanings of Dress. New York: Fairchild.

De Houwer, A. \& Wilton, A. (Eds) (2011). English in Europe Today. Amsterdam/Philadelphia: John Benjamins.

Díez-Arroyo, M. (2015). 'From the atelier to e-commerce: a cognitive approach to neologisms in Spanish fashion.' Terminology, 21(1), 51-75.

Díez-Arroyo, M. (2016a). English words as euphemisms in Spanish Fashion. English Today, 32(3), 30-39.

Díez-Arroyo, M. (2016b). Vagueness: A Loanword's Good Friend. The Case of 'Print' in Spanish Fashion. Pragmatics, 26(4), 609-629.

Fischer, R. \& Pulaczewska, H. (Eds.) (2008) Anglicisms in Europe: Linguistic Diversity in a Global Context. Newcastle-upon-Tyne: Cambridge Scholars Publishing.

Flügel, J.C. (1930). The Psychology of Clothes. London: Hogarth Press.

Furiassi, C. (2010). False Anglicisms in Italian. Monza: Polimetrica.

Furiassi, C., Pulcini, V., \& Rodríguez González, F. (Eds.) (2012). The Anglicization of European Lexis. Amsterdam/Philadelphia: John Benjamins Publishing Company.

García Morales, G. (2009). Análisis de los anglicismos léxicos del lenguaje cinematográfico registrados en muestras escritas entre 2002 y 2006. Tesis Doctoral. Las Palmas de Gran Canaria: Universidad de las Palmas de Gran Canaria.

García Morales, G., González Cruz, M.I., Luján García, C. \& Rodríguez Medina, M.J. (2016). La presencia del inglés en la publicidad televisiva española (2013-2015). Madrid: Síntesis.

Gómez Capuz, J. (2001). La interferencia pragmática del inglés sobre el español en doblajes, telecomedias y lenguaje coloquial: una aportación al estudio del cambio lingüístico en curso. Revista electrónica de estudios filológicos, 2. <https://www.um.es/tonosdigital/znum2/estudios/Doblaje1.htm> [22/10/2017]

González Cruz, M.I. \& Rodríguez Medina, M.J. (2016). On the Pragmatic Function of 
Anglicisms: A Case Study, Revista Alicantina de Estudios Ingleses, 24, 257-273.

Görlach, M. (2001). A Dictionary of European Anglicisms. Oxford: Oxford University Press.

Görlach, M. (Ed.) (2002a). English in Europe. Oxford: Oxford University Press.

Görlach, M. (Ed.) (2002b). An Annotated Bibliography of European Anglicisms. Oxford: Oxford University Press.

Görlach, M. (2003). English Words Abroad. Amsterdam/Philadelphia: John Benjamins.

Gottlieb, H. \& Furiassi, C. (2015). Getting the grips with false loans and pseudo-Anglicisms. In C. Furiassi \& H. Gottlieb (Eds.), Pseudo-English: Studies on False Anglicisms in Europe (pp. 3-33). Boston/Berlin: De Gruyter Mouton.

Haarmann, H. (1986). Verbal strategies in Japanese fashion magazines -a study in impersonal bilingualism and ethnosymbolism. International Journal of the Sociology of Language, 58, 107-121.

López-Zurita, P. (2005). Economic anglicisms: adaptation to the Spanish linguistic system. Ibérica, 10, 91-114.

Lopriore, L. \& Furiassi, C. 2015. The influence of English and French on the Italian language of fashion: focus on false Anglicisms and false Gallicisms. In C. Furiassi \& H. Gottlieb (Eds.), Pseudo-English. Studies on False Anglicisms in Europe (pp. 197-226). Berlin: Walter de Gruyter.

Lorenzo, E. (1996). Anglicismos hispánicos. Madrid: Gredos.

Luján-García, C. (2010). La presencia de la lengua inglesa en carteles publicitarios en las calles de Las Palmas de Gran Canaria. Miscelánea, 41, 13-36.

O'Hara, G. (1986). The Encyclopedia of Fashion. London: Thames.

Onysko, A. \& Winter-Froemel, E. (2011). Necessary loans - luxury loans? Exploring the pragmatic dimension of borrowing. Journal of Pragmatics, 43(6), 1550-1567.

Oxford English Dictionary. (2017). Oxford: Oxford University Press.

Pennycook, A. (1994). The cultural politics of English as an international language. New York: Longman.

Phillipson, R. (2003). English-only Europe? Challenging language policy. London: Routledge.

Pratt, C. (1980). El anglicismo en el español peninsular contemporáneo. Madrid: Gredos.

Price, G. (2014). English for all? Neoliberalism, globalization, and language policy in Taiwan. Language in Society, 43(5), 567-589.

Rodríguez González, F. (1994). Anglicismos en el argot de la droga. Atlantis, 16(1-2), 179216.

Rodríguez González, F. (1999). Anglicisms in Contemporary Spanish. An Overview. Atlantis, 21(1-2), 103-139. 
Rodríguez González, F. (2012). Anglicismos en el mundo del deporte: variación lingüística y sociolingüística. Boletín de la Real Academia Española, 92(306), 317-341.

Rodríguez González, F. (2016). Prólogo. In G. García Morales, M.I. González Cruz, C. Luján García \& M.J. Rodríguez Medina, La presencia del inglés en la publicidad televisiva española (2013-2015) (pp. 7-14). Madrid: Síntesis.

Rodríguez González, F. (2013). Pseudoanglicismos en español actual. Revisión crítica y tratamiento lexicográfico. Revista Española de Lingüística (RSEL), 43(1), 123-170.

Rodríguez Medina, M.J. (2016). The use of anglicisms in Spanish television commercials of cosmetics, hygiene and personal care products. Hermes. Journal of Language and Communication in Business, 55, 157-169.

Rodríguez Segura, D. (1999). Panorama del anglicismo en español. Presencia y uso en los medios. Almería: Servicio de publicaciones de la Universidad de Almería.

Sánchez, S. \& Durán, R. (2002). Una aproximación pragmática al uso de anglicismos en el derecho español. ELIA, 3, 249-258.

Urrutia Cárdenas, H. (2001). La lengua en los medios de comunicación. Onomazein, 6, 1130. 


\section{Appendix}

\begin{tabular}{|c|c|c|c|c|c|c|c|c|}
\hline \multirow[b]{3}{*}{ Magazine } & \multicolumn{7}{|c|}{ Adjectival uses of it } & \\
\hline & \multicolumn{3}{|c|}{ Direct borrowing } & \multirow[b]{2}{*}{$\begin{array}{c}i t+ \\
\text { Spanish } \\
\text { noun }\end{array}$} & \multicolumn{3}{|c|}{$\begin{array}{c}\text { Spanish element or } \\
\text { phrase }+i t\end{array}$} & \\
\hline & $\begin{array}{c}\text { Construction } \\
\text { "it + } \\
\text { Eng. } \\
\text { noun" }\end{array}$ & "it girl" & $\begin{array}{l}\text { Sub- } \\
\text { total }\end{array}$ & & $\begin{array}{l}\text { Sp. } \\
\text { form } \\
+i t\end{array}$ & $\begin{array}{c}\text { "más } \\
\text { (que) } \\
i t " \\
\end{array}$ & $\begin{array}{l}\text { Sub- } \\
\text { total }\end{array}$ & Total \\
\hline Cosmopolitan & 4 & 41 & 45 & 3 & 12 & - & 12 & 60 \\
\hline Elle & 27 & 45 & 72 & 1 & 8 & - & 8 & 81 \\
\hline Glamour & 3 & 22 & 25 & - & 15 & 1 & 16 & 41 \\
\hline Hola Fashion & 4 & 63 & 67 & - & 11 & 3 & 14 & 81 \\
\hline InStyle & 5 & 13 & 18 & - & 5 & 1 & 6 & 24 \\
\hline Marie Claire & 1 & 9 & 10 & - & 1 & - & 1 & 11 \\
\hline Vogue & 5 & 7 & 12 & - & 4 & 2 & 6 & 18 \\
\hline Total & 49 & 200 & 249 & 4 & 56 & 7 & 63 & 316 \\
\hline
\end{tabular}

Table 2. Distribution of adjectival uses of "it" depending on magazine

\begin{tabular}{|l|c|}
\hline \multicolumn{1}{|c|}{ Magazine } & Nominal uses of it \\
\hline Cosmopolitan & 2 \\
\hline Elle & - \\
\hline Glamour & - \\
\hline Hola Fashion & 13 \\
\hline InStyle & - \\
\hline Marie Claire & - \\
\hline Vogue & 2 \\
\hline Total & 17 \\
\hline
\end{tabular}

Table 3. Distribution of nominal uses of "it" depending on magazine

\begin{tabular}{|l|c|c|c|}
\hline \multicolumn{1}{|c|}{ Magazine } & $\begin{array}{c}\text { Total number } \\
\text { of } i t \\
\text { occurrences }\end{array}$ & $\begin{array}{c}\text { Number of } \\
\text { magazine issues }\end{array}$ & It distribution \\
\hline Cosmopolitan & 62 & 33 & $1.87 \%$ \\
\hline Elle & 81 & 19 & $4.26 \%$ \\
\hline Glamour & 41 & 14 & $2.92 \%$ \\
\hline Hola Fashion & 94 & 16 & $5.87 \%$ \\
\hline InStyle & 24 & 21 & $1.14 \%$ \\
\hline Marie Claire & 11 & 21 & $0.52 \%$ \\
\hline Vogue & 20 & 16 & $1.25 \%$ \\
\hline
\end{tabular}

Table 4. Percentage of "it" distribution per magazine issue 